\title{
The potential of white-oyster mushroom (Pleurotus ostreatus) as antimicrobial and natural antioxidant
}

\author{
SAAT EGRA ${ }^{1, \vartheta}$, IRAWAN WIJAYA KUSUMA ${ }^{2, v v}$, ENOS TANGKE ARUNG ${ }^{2, v \vee v, ~ H A R L I N D A ~ K U S P R A D I N I ~}{ }^{2, v v \vee v}$ \\ ${ }^{1}$ Department of Agrotechnology, Faculty of Agriculture, Universitas Borneo Tarakan. Jl. Amal Lama No. 1, Tarakan 77123, North Kalimantan, \\ Indonesia. "email: saat.egra.shaumi@gmail.com \\ ${ }^{2}$ Faculty of Forestry, Universitas Mulawarman. J1. Penajam, Samarinda 75123, East Kalimantan, Indonesia. Tel.: +62-541-749068, Fax.: +62-541-735379, \\ vvemail: kusuma_iw@yahoo.com, vw»tangkearung@yahoo.com, vwrvalinkuspra@gmail
}

Manuscript received: 29 September 2019. Revision accepted: 16 January 2019.

\begin{abstract}
Egra S, Kusuma IW, Arung ET, Kuspradini H. 2019. The potential of white-oyster mushroom (Pleurotus ostreatus) as antimicrobial and natural antioxidant. Biofarmasi J Nat Prod Biochem 17: 14-20. White-oyster mushroom (Pleurotus ostreatus) is a favorite meal in Indonesia. Previously, this fungus was known as a useless plant, but everything changes after the nutrition is known. People try to cultivate it because the nutrients contents are very good for body health. Therefore, this research needs to be done to support this added value in health, especially antimicrobials and antioxidants. This research used successive extraction with hexane solvent, acetate ethyl, ethanol, water, and crude ethanol by antimicrobial assay, antioxidants assay (DPPH), total antioxidant content, and total phenolic content. The highest results on the antimicrobial barrier test against Candida albicans bacteria was $47.60 \%$ with 100 ppm concentration. While on antimicrobial assay using Propionibacterium acnes bacteria, there was no significant inhibition. Regarding the antioxidant test against DPPH, the result showed the occurrence of free radicals by $25 \%$ on water extraction at a concentration of $100 \mathrm{ppm}$. Continuously, the total antioxidant content assay showed that ethyl acetate had the highest value of $368.708 \mathrm{mg}$ gae/gr. The total content phenolic assay results showed that the solvent hexane had a $78.495 \mathrm{mg}$ gae/gr value. These findings indicated that the mushroom has an active phenolic compound with no contribution to impede its working on Candida albicans assay.
\end{abstract}

Keywords: Antimicrobial, total antioxidant, total phenol, white-oyster mushroom

\section{INTRODUCTION}

Mushrooms became more popular in Indonesia when people realized their benefits. Over the years, people have consumed several varieties of mushrooms, such as whitepink oysters, shitake, black jelly, and straw mushrooms, because of their benefits. Today, mushrooms have been processed and consumed in various forms as vegetables, crackers, and herbs for health purposes. Most Indonesian people start cultivating oyster mushrooms because of their efficacy and high economic value, and they provide high income for cultivators. Nasrul (2004) stated that historically, it had been used as food since 3,000 years ago, exclusively presented to the King of Egypt, while the Chinese have used it as herbs since 2,000 years ago.

Mushrooms are highly nutritious and cholesterol-free foods (Nasrul 2004). Sumarmi (2006) states that 100 grams of oyster mushrooms contain protein (19-35\%) which consists of 9 amino acids; fat (1,7-2,2\%), in which $72 \%$ are unsaturated fatty acids, carbohydrates, vitamins $\mathrm{B}$ (thiamin, riboflavin, and niacin), vitamin $\mathrm{D}$ and $\mathrm{C}$, minerals (K, P, Na, Ca, Mg, Zinc, Fe, Mn, Co, and $\mathrm{Pb}$ ), and the levels of metal-microelements are very low, so it is safe to be consumed every day.

According to Chang and Buswell (1996), mushrooms are delicious food. Some mushrooms have been known to have biological activities such as anti-cancer, anti-diabetes, overcoming hyperlipidemia, and increasing the immune system. According to Bobek et al. (1998), oyster mushrooms are good for cardiovascular patients and can control cholesterol levels. The community owns limited knowledge about the benefits of mushrooms, so they consume them only as additional dishes. This research was conducted to determine the potential of white-oyster mushrooms (Pleurotus ostreatus) as antimicrobial and natural antioxidants.

\section{MATERIALS AND METHODS}

\section{Plant materials and chemicals}

This research was carried out at the Chemistry Laboratory, Department of Forest Products Technology, Faculty of Forestry, Mulawarman University, Samarinda, Indonesia. The research material (fresh oyster mushrooms) was obtained from the Faculty of Forestry, Mulawarman University, Samarinda, Indonesia. The chemical used are $n$ hexane, ethyl acetate, ethanol, acetone, isolates of Propionibacterium acnes and Candida albicans provided by Forest Products Chemistry Laboratory in Mulawarman University, nutrients agar (Difco, USA), chloramphenicol, and glucose (Merck, Germany). The equipment used in this research was Shimadzu UV-VIS 1240 spectrophotometer (Shimadzu, Japan), an evaporator (Eyela, Japan), and an autoclave provided by all American Model 25X-2.

\section{Extraction}

White-oyster mushroom (Pleurotus ostreatus) (500 grams) was cut into small pieces and dried at $39 \mathrm{oC}$ for 48 
hours in the oven. The dried mushroom was ground into a coarse powder in a blender. The powder was extracted successively with $n$-hexane, ethyl acetate, and ethanol. The powder was extracted separately with ethanol to obtain crude ethanol. The extraction was conducted at room temperature with continuous shaking on a shaker (7400 Tübingen; EdmunBuchler, Germany) for $48 \mathrm{~h}$., followed by filtration of suspension with Whatman filter paper No. 2 (Maidstone, UK). The crude alcohol extracts were evaporated at $40^{\circ} \mathrm{C}$ and put in a vacuum oven to near-dried extracts to yield the mushroom extracts.

\section{Antimicrobial assay}

Antimicrobial assays were conducted using the agar well disk diffusion method of Kuspradini (2012). Propioni bacterium acnes and Candida albicans were used in all experiment. Nutrient agar (Difco) was the main media to culture bacteria. $20 \mathrm{~mL}$ aliquots of sterile media were transferred to Petri dishes and allowed to solidify. The media were inoculated with $20 \mu \mathrm{L}$ of microbial suspension spread uniformly on the surface of the plates. After that, the media agar plates were cut using a sterile cork-borer with a size seven-mm well, and a $20 \mu \mathrm{L}$ acetone solution containing 25-100 $\mu \mathrm{g}$ extracts was added to the well. Chloramphenicol was used as a positive control at the concentration of $10 \mu \mathrm{g} / 20 \mu \mathrm{L}$ in each well. The plates were incubated in the dark at $32^{\circ} \mathrm{C}$ for $24 \mathrm{~h}$. Microbial activity was measured $(\mathrm{mm})$ by the existence inhibiting zone around agar diffusion well-containing extract. Microbial activity was calculated as the mean inhibition zone for the test sample divided by the mean inhibition zone for the standard drug. (Kuspradini 2012).

\section{Total antioxidant capacity}

Total antioxidant capacity was evaluated according to the method described by Prieto et al. (1999). $5 \mathrm{mg}$ sample was dissolved in $1000 \mu \mathrm{L}$ ethanol. $100 \mu \mathrm{L}$ sample solution was added by $1 \mathrm{~mL}$ Reagent $(0.6 \mathrm{M}$ sulfuric acid $+28 \mathrm{mM}$ sodium phosphate $+4 \mathrm{mM}$ ammonium molybdates). Then, the sample was incubated in a water bath shaker at $95^{\circ} \mathrm{C}$ for 90 minutes and cooled to room temperature. Measurement was made using a spectrophotometer with an absorbance wavelength of $695 \mathrm{~nm}$. The gallic acid was used as a standard on 0.02 in $0.1 \mathrm{mg} / \mathrm{mL}$ and ethanol as a blank.

\section{Total phenolic content}

Total phenolic content was determined using the method by Slinkard and Singleton (1977). The sample (5 $\mathrm{mg}$ ) was dissolved in $1000 \mu \mathrm{L}$ ethanol. $20 \mu \mathrm{L}$ sample solution was added to the tube with $100 \mu \mathrm{L}$ ( 2 N Reagan Folin-Ciocalteu) and $300 \mu \mathrm{L}$ from $0.2 \mathrm{mg} / \mathrm{mL}$ solution of sodium carbonate and $1180 \mu \mathrm{L}$ aquadest, and the volume growth of $1600 \mu \mathrm{L}$ in the reactive tube. Incubation was done at a temperature of $37^{\circ} \mathrm{C}$ for 2 hours. The measurement was conducted with a spectrophotometer with a wavelength absorbance of $760 \mathrm{~nm}$. Gallic acid was used as standard.

\section{Total flavonoid content}

Total flavonoid content was determined using the method of Choi et al. (2006). $5 \mathrm{mg}$ sample was dissolved in $1000 \mu \mathrm{L}$ ethanol. $250 \mu \mathrm{L}$ of the sample solution was put into a test tube and added with $1.25 \mathrm{~mL}$ of distilled water and $75 \mu \mathrm{L}$ of $5 \% \quad \mathrm{NaNO}_{2}$ and incubated at room temperature for 5 minutes. $150 \mu \mathrm{L}$ was added from $10 \%$ $\mathrm{AlCl}_{3}$ and incubated at room temperature for 6 minutes. Then it was added with $500 \mu \mathrm{L}$ of $1 \mathrm{M} \mathrm{NaOH}$ and $275 \mu \mathrm{L}$ of distilled water, and was incubated for 20 minutes for a reaction. Measurements were carried out with a spectrophotometer with an absorbance of $510 \mathrm{~nm}$ using distilled water as a blank.

\section{RESULTS AND DISCUSSION}

\section{Extraction}

The extraction method used was successive maceration at room temperature which three different solvents ( $n$ hexane, ethyl acetate, and ethanol). The ideal solvent for the extraction process must have some conditions, namely: (i) it must be able to dissolve the extractive substances, (ii) it must have a similar boiling level to the substance, and (iii) it must be inert (it does not react with substances that will be extracted, (iv) it must have a low boiling point for easy evaporation, but not too low that it can cause the loss of some solvents as a result of the evaporation (Guenther 1987). The extraction is started by macerating the sample for 24 hours with $n$-hexane. The filtrate was filtered with filter paper and evaporated to obtain concentrated hexane extract. The powder of mushroom, which had been extracted with hexane, was re-extracted with ethyl acetate followed by ethanol.

The extract yield can be used as a reference to find out the amount of simplicial needed to make a certain number of thick extracts. According to Lo et al. (1983), the extraction method is one of the factors that will affect the yield of an extract. Extraction using solvents consists of several methods, including maceration, percolation and heat methods, reflux, soxhletation, infusion, decadence, and digestion. Besides, the amount of extract is also influenced by the polarity index in the solvent; the lowest to highest polarity index in this study is, respectively, hexane, ethyl acetate, and ethanol.

Table 1 showed that the highest yield of extract was with the ethanol extract $(7.88 \%)$, while with the hexane extract, it was less than $1 \%(0.51 \%)$. The yield on extracting mushrooms with acetate ethyl was $6.02 \%$. The $n$-hexane solvent has $0.51 \%$ yield.

Table 1. Yield of oyster mushroom extract in several solvents

\begin{tabular}{lccc}
\hline Extract & $\begin{array}{c}\text { Sample } \\
\text { weight }(\mathbf{g})\end{array}$ & $\begin{array}{c}\text { Extract } \\
\text { yield }(\mathbf{g})\end{array}$ & Extract $(\%)$ \\
\hline n-Hexane & 40 & 0.18 & 0.51 \\
Ethyl acetate & 40 & 2.14 & 6.02 \\
Ethanol & 40 & 2.80 & 7.88 \\
Crude ethanol & 23 & 0.08 & 0.39 \\
\hline
\end{tabular}

Note: The percentage of dried-mushroom extract based on the weight 


\section{Antimicrobial activity}

Antimicrobial assay on white-oyster mushroom ( $P$. ostreatus) was done against $P$. acnes and $C$. albicans with agar diffused method. Chloramphenicol was used as a positive control because it has broad spectrum as antibacterial, while acetone was used as a negative control. Microbial resistance to antibiotics is a major problem today. Many biological active components released from plant species are commonly used as drugs, because they can offer a new source of antimicrobial activity. The search for antimicrobial bioactivity from natural materials gives the result of antimicrobial activity from white oyster mushroom (Pleurotus ostreatus) which is shown in Table 2.

Chloramphenicol with the zone barriers $24.5 \mathrm{~mm}$ has presented the results of the test activity of bacteria $P$. acnes. This study showed the extract has no resistance to $P$. acnes. This indicates that there is no active anti-bacterial compound towards $P$. acnes. The absence of active compounds in the extract is thought to be due to very little concentration, perhaps if the concentration is raised it will increase inhibition. Antimicrobial activity of oyster mushroom extract has also conducted against one of the fungus, $C$. albicans. The results of the assay displayed that oyster mushroom extract indicated the formation of barriers on some level zone concentration of extract. Mushroom extract on the concentration of $25 \mu \mathrm{g}$ showed the lowest activities of anti-candida with inhibition of $8.53 \mathrm{~mm}$ width. Increasing inhibition activity was shown on the concentration of $50 \mu \mathrm{g}$ with inhibition of $10.5 \mathrm{~mm}$ width. The best activities were indicated by mushroom extract on the concentration of $100 \mu \mathrm{g}$ with inhibition of $10.8 \mathrm{~mm}$ width. Davis and Stout (1971) reported the inhibiting diameter regions on $5 \mathrm{~mm}$ or less then inhibiting activities is categorized as weak; $5-10 \mathrm{~mm}$ is categorized as medium; $10-19 \mathrm{~mm}$ is categorized as strong, whilst $20 \mathrm{~mm}$ or more is categorized as very strong.

Table 2 showed the inhibition as a whole in medium category as it is around $8-10 \mathrm{~mm}$. Of all solvent, the highest barriers was produced on the rough extract ethanol with $10.8 \mathrm{~mm}$. It was identified on the concentration 100 $\mu$ g. Oyetayo (2009) reported that fungus extracts are able to inhibit the growth of all kinds of organisms on the concentration between $12.5 \mathrm{mg} / \mathrm{mL}$ until $100 \mathrm{mg} / \mathrm{mL}$. This research used the less concentration, $25 \mu \mathrm{g}, 50 \mu \mathrm{g}, 100 \mu \mathrm{g}$, and these concentrations have been able to inhibit the growth of the mushroom $C$. albicans.

Nwachukwu and Uzoeto (2010) found that the hot water extract of the R. vesca mushroom is able inhibiting the growth of E. coli, S. typhi, P. mirabilis, and $C$. albicans. The ethanol extraction of A. auricular showed a broad spectrum of microbial effect against microorganisms experiment with the exception of $S$. tophi and $P$. aeruginos. $P$. squarrosulus displaying the microbial activity against $K$. pneumonia $(6,14 \mathrm{~mm}), S$. pneuoniae $(5.12 \mathrm{~mm})$, and $C$. albicans $(4.10 \mathrm{~mm})$. $P$. aeruginosa has swapped off almost all extract from four species of fungus except hot water extraction from $P$. squarrosulus which shows the inhibition zone $(3.41 \mathrm{~mm})$. V. vulvae showed the microbial activity against S. typhi (4.60 mm). However, Vamanu (2012) reported, the $P$. ostreatus is able to inhibit Candida albicans with MIC 12.5, 12.5, 25, $25 \mathrm{mg} / \mathrm{mL}$, continuously on a different nitrogen source, corn, malt, and yeast extraction, and peptone used on the culture media.

Table 2. antimicrobial activity of oyster mushroom against Candida albicans

\begin{tabular}{|c|c|c|c|c|c|c|c|c|}
\hline \multirow{2}{*}{$\begin{array}{l}\text { Sample } \\
\text { extracts }\end{array}$} & \multicolumn{4}{|c|}{ Inhibition (mm) } & \multicolumn{4}{|c|}{ Inhibition (\%) } \\
\hline & $25 \mu \mathrm{g}$ & $50 \mu g$ & $100 \mu g$ & $(+)$ & $25 \mu \mathrm{g}$ & $50 \mu g$ & $100 \mu g$ & $(+)$ \\
\hline$n$-Hexane & 9.86 & 9.46 & 8.63 & 23.76 & 41.5 & 39.8 & 36.3 & 100 \\
\hline Ethyl acetate & 9.76 & 9.96 & 9.7 & 21.86 & 44.65 & 45.56 & 44.4 & 100 \\
\hline Ethanol & 8.53 & 9.16 & 9.06 & 23.96 & 35.6 & 38.2 & 47.6 & 100 \\
\hline Crude ethanol & 9.3 & 10.5 & 10.8 & 22.7 & 40.96 & 46.3 & 37.8 & 100 \\
\hline
\end{tabular}

Note: (+) is a positive control (Chloramphenicol)
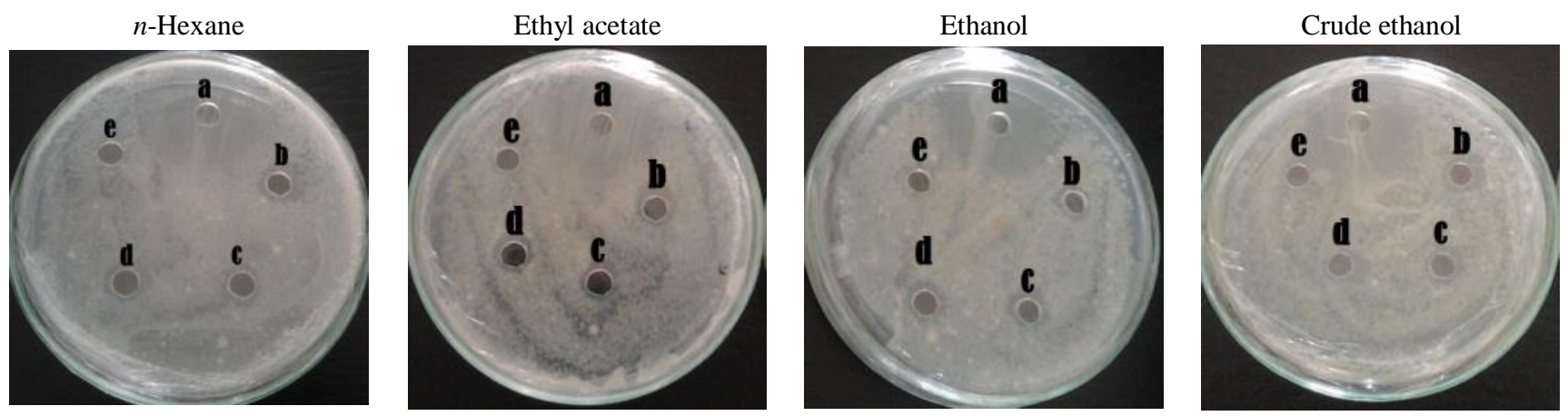

Picture 1. Inhibition of oyster mushroom against Candida albicans. (a) control (-); (b) control (+); (c) concentration $100 \mu \mathrm{g}$; (d) concentration $50 \mu \mathrm{g}$ and (e) concentration $25 \mu \mathrm{g}$ 
Hapsari et al. (2012) reported that the chemical composition at oyster mushroom is alkaloid, saponin, phenolic, and tannin. Tannin plays important role in degradation of microbial cell wall. Ajizah (2004) reported, tannin also has antibacterial capability by precipitating proteins. The effect of antibacterial tannin is through the reaction with the membrane cell, inactivation enzymes, and function of genetic material. This condition makes some fungi used extensively as food for its nutrition in traditional medicine (Stamets 2000; Lindequist et al. 2005). The strong activity of plant extracts against $C$. albicans shows the potential for use as a drug for candidemia, nosocomial infections, and diseases caused by other Candida infections

\section{DPPH antioxidant activity}

Antioxidant assay was done by scavenging free radicals which are measured at spectrophotometer with DPPH free radicals agent. The positive control used vitamin $\mathrm{C}$ because it is known as the best natural antioxidant. The number of free radical scavenging activity is presented as the percentage of the inhibition with an indication of color changes of DPPH. The result of the antioxidant activity mushroom extract oysters is presented in Table 3.

Table 3 displayed that the antioxidants activity by scavenging free radical DPPH is influenced by the type of extraction and concentration levels. The crude ethanol provided the highest inhibition by $21.43 \%$ on the concentration of $100 \mathrm{ppm}$. The results indicated that the use of higher concentrations is potential to improve antioxidant activity. These active compounds were soluble on the ethanol extraction.

Antioxidant activity assay aimed to find out how big a plant will be able to scavenge free radicals. Mechanism of scavenging free radicals is by inhibiting lipid oxidation that can be used to calculate the activity of antioxidant (Pornariya 2009). The crude ethanol extract showed relatively better inhibition with $21.43 \%$ on $0.1 \mathrm{mg} / \mathrm{mL}$ even though it was still lowest than vitamin $\mathrm{C}$ which was used as a positive control. Mau et al. (2001) and Lo (2005) found that free radical activity in oysters mushroom towards DPPH was $81.8 \%$ on $6.4 \mathrm{mg} / \mathrm{mL}$ and $68.4 \%$ on 5 $\mathrm{mg} / \mathrm{mL}$. It specified that extracting concentration on antioxidant activity assay plays an important role to produce the high antioxidant activity.

White Oyster mushroom (Pleurotus ostreatus) is able to be an antioxidant because it provides phenolic, L-ergotien, selenium compound and vitamin C (Jayakumara et al 2006). Phenolic compounds are capable to inhibit the oxidation reaction and reduce hydroxyl radical, superoxide, and peroxide. Phenolic also has an effect on the process of synthesis transcription of endogenous antioxidant, namely glutation (Khotimah 2008). $250 \mathrm{mg} / \mathrm{kg} \mathrm{BW}$ white oyster mushroom extraction has a great antioxidant effect because it contains antioxidant substances, phenol, ergotien, vitamin $\mathrm{C}$, selenium, and beta-carotene. Phenol compound is the component with the highest antioxidant activity on white oysters mushroom. The research to find antioxidant compounds must continue to be done, because it is very important in finding solutions to diseases caused by free radicals, in testing oxidative reactions in food, and in protecting against DNA damage and carcinogenesis. In the future this substance will function in many ways such as pharmacological activity; anti-inflammatory, anti-bacterial, and anti-fungal.

\section{Total antioxidant capacity}

Total antioxidant content assay has been done to find out how many active compounds are able to scavenge free radicals on the mushroom. Surekha et al. (2011) concluded that mushroom is healthy food, moreover its rich protein and antioxidant compounds which are essential compound are able to fight disease. Total antioxidant content assay results from several extraction methods on mushroom are presented in Table 4.

Table 4 showed that the oyster mushroom extractions have good antioxidant activity. The ethyl acetate has the highest antioxidant content values which are followed by hexane extract, ethanol, and crude ethanol extract. Table 4 displayed the different colors on the assay solvent indicating the existing active compounds. Polyphenol is one of contributed antioxidant activity on the fruit, vegetables, and fungus (Ferreira et al. 2007).

Table 3. Antioxidant activity of oyster mushroom extract against $\mathrm{DPPH}$

\begin{tabular}{lccc}
\hline \multirow{2}{*}{ Sample } & \multicolumn{3}{c}{ Inhibition (\%) } \\
\cline { 2 - 4 } & $\mathbf{2 5} \mathbf{~ p p m}$ & $\mathbf{5 0} \mathbf{~ p p m}$ & $\mathbf{1 0 0} \mathbf{~ p p m}$ \\
\hline Vitamin C (positive control) & 96.84 & 96.84 & 96.85 \\
n-hexane & 3.92 & 2.41 & 0.30 \\
Ethyl acetate & 2.72 & 2.72 & 6.34 \\
Ethanol & 2.25 & 8.20 & 13.88 \\
Crude ethanol & 17.85 & 17.85 & 21.43 \\
\hline
\end{tabular}

Table 4. The total antioxidant capacity of Oysters mushroom

\begin{tabular}{lcccc}
\hline \multirow{2}{*}{ Samples } & \multicolumn{3}{c}{ Absorbance } & Antioksidan \\
\cline { 2 - 4 } & Rep. 1 & Rep. 2 & Rep. 3 & $\begin{array}{c}\text { capacity } \\
\text { (mg GAE/g) }\end{array}$ \\
\hline n-hexane & 1.283 & 1.238 & 1.352 & 313.625 \\
Ethyl acetate & 1.485 & 1.523 & 1.526 & 368.702 \\
Etanol & 0.548 & 0.563 & 0.544 & 128.792 \\
Crude Etanol & 0.479 & 0.502 & 0.505 & 114.708 \\
\hline
\end{tabular}

Note: Rep.= Repetition

Table 5. The total phenolic content of oyster mushroom

\begin{tabular}{lcccc}
\hline \multirow{2}{*}{ Samples } & \multicolumn{3}{c}{ Absorbance } & Antioksidan \\
\cline { 2 - 4 } & Rep. 1 & Rep. 2 & Rep. 3 & $\begin{array}{c}\text { capacity } \\
\text { (mg GAE/g) }\end{array}$ \\
\hline n-hexane & 0.28 & 0.3 & 0.28 & 78.495 \\
Ethyl acetate & 0.23 & 0.2 & 0.21 & 57.733 \\
Etanol & 0.07 & 0.09 & 0.1 & 22.495 \\
Crude Etanol & 0.09 & 0.08 & 0.09 & 21.352 \\
\hline
\end{tabular}

Note: Rep.= Repetition 

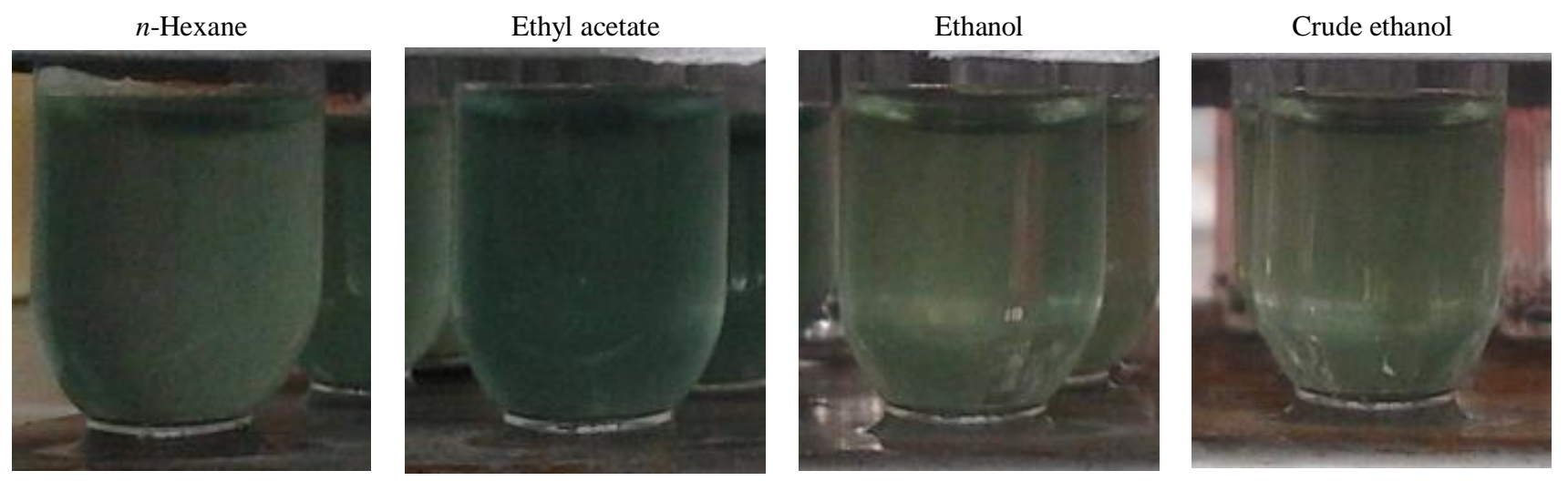

Figure 2. The result of total antioxidant capacity assay
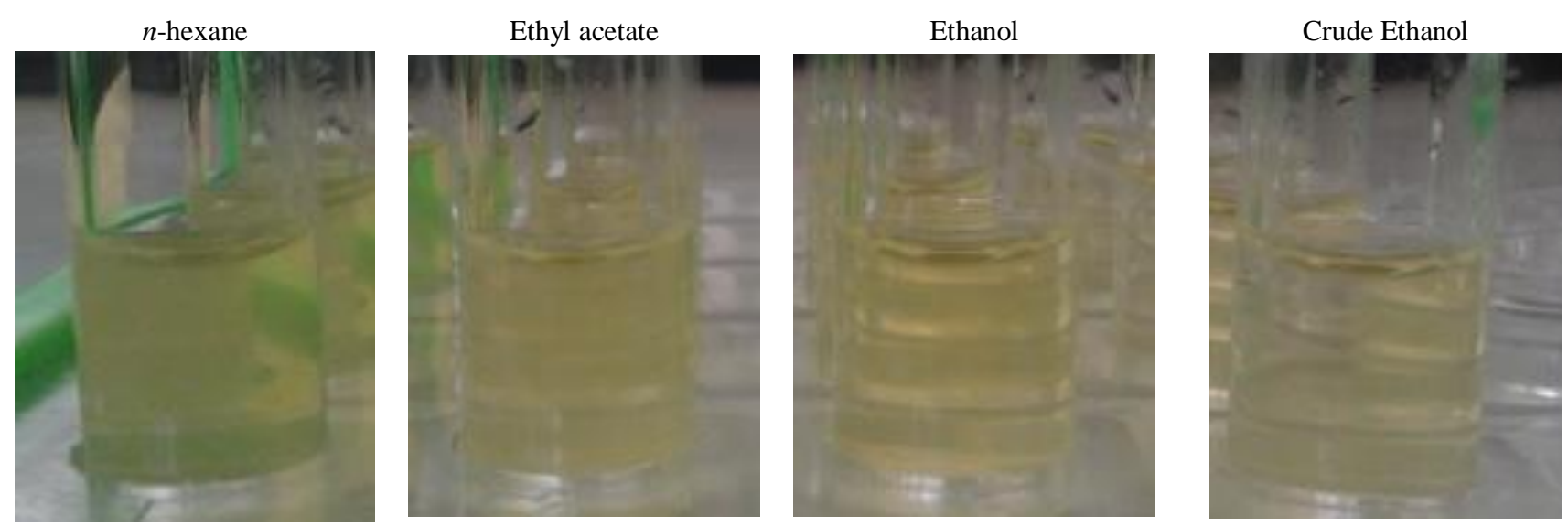

Figure 3. The result of total antioxidant content

The high antioxidant content on oyster mushroom extract allegedly because the polyphenol is found on the oyster mushroom. Hapsari et al. (2012) reported that oyster mushroom extraction has antioxidant and tyrosine activities with the result that the ethanol extraction has higher activity than water extraction. It indicated that solvent ethanol is more dissolving antioxidants active compounds than water which is polar. The Culinary-medicinal mushroom research which found a good antioxidant content and potentially antihypertensive can be seen from the occurrence of inhibition of oyster mushroom to ACE (angiotensin I-converting enzyme).

\section{Total phenolic content}

Total phenolic content assay have been done to find out how much the content of active phenol compounds on the oyster mushroom. Phenol components, flavonoid, anthocyanin, and carotenoids develop the main components of the natural antioxidant which scavenging free radicals due to its ability to divide the hydrogen atoms or electron and the balance of radical compound (Shahidi and Wanasundra 1992). Table 5 shows the results in total phenolic content from oyster mushroom extract on some of the solvents.
Table 5 presented that the highest rate of phenol content is from the extract by hexane followed by ethyl acetate, ethanol and crude ethanol which indicates that oyster mushroom has active phenolic compounds. Alvarez (2007) reported that mushroom can be used as the source of low calories and fat on food with the high polyphenol and antioxidants activity level. Phenol compound is the component with the highest antioxidant activity on the white-oyster mushroom. The activities are not only mainly caused by the capability in reducing hydrogen and singlet oxygen quencher but the component also has the potential metal chelation effect (Polite 2010).

Phenolic acid plays the main role to phenolic components in the mushroom (Ferreira 2009). According to Puttaraju (2006), galic, tannin, protocatechuic, and gantesik acids are some main phenolic content detected in the water extraction from some Indian mushroom traditional food. Abdullah et al. (2012) stated that the total phenolic from some varieties of mushroom extraction assay started at 6.19 to $63.51 \mathrm{mg} \mathrm{GAE} / \mathrm{g}$ with $\mathrm{G}$ lucidum having the highest phenolic content $(63.51 \pm 1.11 \mathrm{mg} \mathrm{GAE} / \mathrm{g})$. Iwalokun (2007) reported the phenolic content and the antioxidant content on acetone extract of $P$. ostreatus is equal to petroleum ether extract of $P$. ostreatus. 

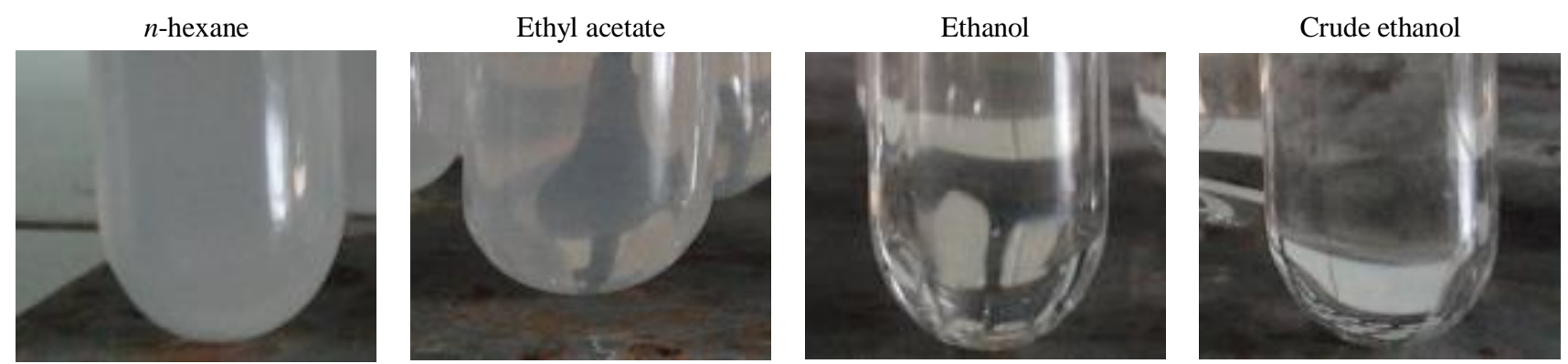

Figure 4. The result of total flavanoid content

Table 6. The total flavonoid content of white oyster mushroom

\begin{tabular}{lcccc}
\hline \multirow{2}{*}{ Samples } & \multicolumn{3}{c}{ Absorbance } & Antioksidan \\
\cline { 2 - 4 } & Rep. 1 & Rep. 2 & Rep. 3 & $\begin{array}{c}\text { capacity } \\
\text { (mg GAE/g) }\end{array}$ \\
\hline n-hexane & 1.758 & 1.905 & 1.461 & 653.5 \\
Ethyl acetate & 0.357 & 0.394 & 0.231 & 122.474 \\
Etanol & 0 & 0 & 0 & 0 \\
Crude Etanol & 0 & 0 & 0 & 0 \\
\hline
\end{tabular}

\section{Total flavonoid content}

Total flavonoid content assay has been done to find out how much the active compound of flavonoids in oyster mushrooms. Flavonoids are usually glycosylated and can be classified as anthocyanidins, flavanols (catechins), Flavone, flavanone, and flavonol, which are commonly found in fruits and vegetables in orange, red, and blue. Generally, they are found in light-colored fruit, vegetables or foods that are known to be healthy for the human body (Lin and Tang 2007). Table 6 shows that oyster mushroom extract has flavonoid levels. The highest level of flavonoid is in hexane solvent and is followed by ethyl acetate.

The highest flavonoid content in hexane is probably due to the density that occurs because of the reaction of the reagent solvent as shown in Figure 5. It is caused by hexane which has non-polar properties, so it has no ability to attract or dissolve active flavonoid compounds in oyster mushrooms. Hapsari et al. (2012) reported that from the chemical composition of the oyster mushroom simplicia, the presence of alkaloids, saponins, phenols, and tannins has been detected, but the presence of flavonoids was undetected. This was confirmed by Kim's research (2009) reporting that carotenoids such as lutein, lycopene, $\beta$ carotene, zeaxanthin staining were not detected in oyster mushroom. The absence of flavonoids in oyster mushrooms is probably a biological factor and a factor in the ecology of oyster mushrooms because the bioactive components inhibit enzyme activity (tyrosinase) for the development process and growth of oyster mushroom pigmentation (Xie et al. 2003).

\section{ACKNOWLEDGEMENTS}

The source of the research raw material was obtained from the entrepreneurial student's team of Forestry Faculty, Mulawarman University, planted by Saat Egra, Henderson Saragih, Sopian Tambing, Ronal P, Migirin, Jabaruddin, and Raymoon Silaban.

\section{REFERENCES}

Alvarez P. 2007. Total phenol and antioxidant activity of commercial and wild mushrooms from Chihuahua, Mexico. Universidad Autonoma de Ciudad Juarez, Chihuahua, CP 32310 , Mexico.

Ajizah A. 2004. Sensitivitas Salmonella thypimyurium terhadap ekstrak Psidium guajava L. Bioscientiae 1 (1): 31-38. [Indonesian]

Bobek P. 1998. Dose and time dependent hypocholesterolemic effect of oyster mushroom (Pleurotur ostreatus) in rats. Nutrition 14 (3): 28286.

Chang ST, Buswell JA. 1996 Mushroom nutriceuticals. World J Microbiol Biotechnol 12: 473-476

Choi Y, Lee SM, Chun J, Lee HB, Lee J. 2006. Influence of heat treatment on the antioxidant activities and polyphenolic compounds of shitake (Lentinus edodes) mushroom. Food Chem 99: 381-387.

Davis WW, Stout TR. 1971. Disc plate methods of microbiological antibiotic assay. Microbiology 22: 659-665.

Ferreira ICFR, Babtista P, Vilas-Boas M, Barros L. 2007. Free-radical scavenging content and reducing power of wild edible mushrooms from Northeast Portugal: Individual cap and stipe activity. Food Chem 100: 1511-1516.

Ferreira ICFR, Barros L, Abreu RMV. 2009. Antoxidant in wild mushrooms. Curr Med Chem 16 (12): 1543-1560.

Guenther E. 1987. Minyak Atsiri. Universitas Indonesia Press. Jakarta. [Indonesian]

Jayakumara T, Ramesha E, Geraldine P. 2006. Antioxidant activity of the oyster mushroom, Pleurotus ostreatus, on CCI4- induced liver injury in rats. J Food Chem Toxicol 44: 1989-96.

Khotimah S. 2008. Pengaruh pemberian ekstrak jinten hitam (Nigella sativa) terhadap kadar GSH paru dan hepar tikus wistar yang dipapar asap rokok. JPB 8 (2): 55-60. [Indonesian]

Kim JH, Kim SJ, Park HR, Choi JI, Ju YC, Nam KC, Kim SJ, Lee SC. 2009. The different antioksidan and anticancer activities depending on the color of oyster mushrooms. J Med Palnts Res 3 (12): 10161020.

Kuspradini H, Susanto D, Ritmaleni \& Mitsunaga T. 2012. Phytochemical and comparative study of anti microbial activity of Lepisanthes amoena leaves extract. J Biol Agric Healthcare 2 (11): 80-86.

Lo TC, Baird MH, Hanson C. (eds.). 1983. Handbook of solvent extraction. Wiley, New York.

Lo SH 2005. Quality evaluation of agaricus bisporus, Pleurotus eryngii, during postharvest storage. [Thesis]. National Chung-Hsing University, Taichung, Taiwan. 
Lin JY, Tang CY 2007. Determination of total phenolic and flavonoid content and selected fruits and vegetables, as well as their stimulatory effect on mouse splenocyte proliferation. Food Chem 101: 140-147.

Lindequist U, Niedermeyer THJ, Julich W 2005. The pharmacological potentials of mushrooms. Ecam 2: 285-299.

Mau JL, Chao GR, Wu KT 2001. Antioxidant properties of metanolic extract from several ear mushrooms. J Agric Food Chem 49: 54615467.

Nasrul M. 2004. Jamur. Buletin Teknopro Hortikultura (edisi 74, Oktober 2004). Direktorat Pengelolahan dan Pemasaran Hasil Hortikultura Departement Pertanian, Jakarta. [Indonesian]

Abdullah N, Ismail SM, Aminudin N, Shuib AS, Lau BF. 2012 Evaluation of selected culinary-medicinal mushrooms for antioxidant and ACE inhibitory activities. Evid-Based Compl Altern Med 2012: 464238. DOI: $10.1155 / 2012 / 464238$.

Nwachukwu U. 2010. Antimicrobial activity of some local mushrooms on pathogenic isolates. Michael Okpara University of Agriculture. Nigeria, Nigeria.

Oyetayo VO. 2009. Free radical scavening and antimicrobial properties of extracts of wild mushrooms. Federal University of Technology, Nigeria, Nigeria.

Pornariya C. 2009. Amino acids and antioksidan properties of the oyster mushrooms, Pleurotus ostreatus and Pleurotus sajor-caju. Suranaree University of Technology, Thailand.

Prieto P, Pineda M, Aguilar M. 1999. Spectrophotometric quantitation of antioxidant capacity through the formation of a phosphomolybdenum complex: specific application to the determination of vitamin E. Anal Biochem 269 (2): 337-341.

Puttaraju NG, Venkateshaiah SU, Dharmesh SM, Urs SMN, Somansundaram R. 2006, Antioxidant activity of indigenous edible mushrooms. J Agric Food Chem 54 (26): 9760-9772.

Hapsari R, Elya B, Amin J. 2012. Formulation and evaluation of antioxidant and tyrosinase inhibitory effect from gel containing the 70 $\%$ ethanolic Pleurotus ostreatus extract. Intl J Med Arom Plants 2 (1): 135-140.

Shahidi F, Wanasundara PK. 1992. Phenolic Antioxidants. Crit Rev Food Sci Nutr 32: 67-103.

Stamets P. 2000. Growing Gourmet and Medicinal Mushroom. Berkeley Ten press. pp. 23-36.

Sumarmi 2006. Botani dan Tinjauan Gizi Jamur Tiram Putih. Innofarm: Jurnal Inovasi Pertanian 4 (2): 124-130. [Indonesian]

Surekha Ch, Kaladhar DSVGK, Raju Srikakarlapudi JR, Haseena. 2011. Evaluation of antioxidant and antimicrobial potentiality of some edible mushrooms. Intl J Adv Biotech Res 2 (1): 130-134.

Vaamanu E. 2012. In vitro antimicrobial and antioxidant activities of ethanolic extract of lyophilized mycelium of Pleurotus ostreatus PQMZ91109. Molecules 17 (4): 3653-3671.

Xie LP, Chen OX, Huang H, Wang HZ, Zhang RQ. 2003. Inhibitory effects of some flavonoids on the activity of mushroom tyrosinase. Biochemistry (Mosc), 68: 487-491. 